\title{
C Deletion in Exon 4 Codon 63 of p53 Gene in Turkish Patients with Oral Squamous Cell Carcinoma
}

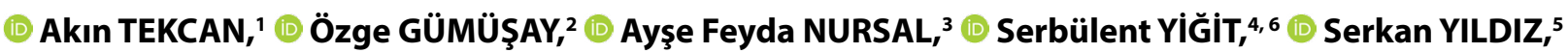 (1) Mehmet Kemal TÜMER ${ }^{5}$}

\author{
'Department of Medical Biology, Amasya University, Faculty of Medicine, Amasya-Turkey \\ ${ }^{2}$ Department of Medical Oncology, Gaziosmanpaşa University, Faculty of Medicine, Tokat-Turkey \\ ${ }^{3}$ Department of Medical Genetics, Hitit University, Faculty of Medicine, Çorum-Turkey \\ ${ }^{4}$ Department of Medical Biology, Gaziosmanpaşa University, Faculty of Medicine, Tokat-Turkey \\ ${ }^{5}$ Department of Oral and Maxillofacial Surgery, Gaziosmanpaşa University, Faculty of Dentistry, Tokat-Turkey \\ ${ }^{6}$ Department of Genetic, Ondokuz Mayıs University, Faculty of Veterinary, Samsun-Turkey
}

\section{OBJECTIVE}

Oral squamous cell carcinoma (OSCC) is the most frequently seen oral malignancy and accounts for up to $80-90 \%$ of all malignant neoplasms that occurin the oral cavity. The p53 tumor suppressor gene plays a crucial role in the regulation of the cell cycle. Mutations of the p53 gene havean important role in OSCC carcinogenesis. In this study, we aimed to evaluate the C-deletion mutation in exon 4 codon 63 of p53 gene in Turkish patients with OSCC.
\end{abstract}

\section{METHODS}

A total of 60 subjects were enrolled in this study, 30 patients with a pathologic diagnosis of OSCC and 30 cases of age and sex-matched healthy controls. Genotyping was performed for all individuals using polymerase chain reaction (PCR) analysis.

\section{RESULTS}

The findings showed that the distribution of $\mathrm{p} 53$ exon 4 codon $63 \mathrm{C}$-deletion was significantly different between patient group and control group $(\mathrm{p}=0.000)$. It was detected that all patients had $\mathrm{C}$-deletion mutation in exon 4 codon 63 of p53.

\section{CONCLUSION}

Our results suggest that $\mathrm{C}$-deletion in exon 4 codon 63 deletion of the p53 gene may play a role in the pathogenesis of human OSCC in a Turkish cohort.

Keywords: Deletion; oral squamous cell carcinoma; p53; PCR.

Copyright $\odot$ 2020, Turkish Society for Radiation Oncology

\section{Introduction}

Oral cancer broadly consists of tumors developing in the lips, hard palate, upper and lower alveolar ridges, anterior part of the tongue, sublingual region, buccal mucosa, retromolartrigone and base of the mouth.[1]
Squamous cell carcinoma is the major histological type (seen in $~ 95 \%$ of the cases). Thus, the term 'oral cancer' is mostly used interchangeably with oral squamous cell carcinoma (OSCC).[2] The three main carcinogenic stimuli, chemical, physical (radiation), and infectious (oncogenic viruses) agents, may cause mutations in 
the oral cavity which may modify the structure of the genes and chromosomes.[3] Mutations may lead to deregulation and constitutive activity, overproduction of a normal gene product, or changes in the biochemical function of the gene product.

p53 gene covers $16-20 \mathrm{~kb}$ of DNA on the short arm of the chromosome 17 and consists of 11 exons and acts as a tumor suppressor gene. p53 functions as a 'guardian of the genome' to sustain the balance of cell death and proliferation by modulating the cell cycle, DNA repair, apoptosis, cellular metabolism and senescence. $[4,5]$ p53 genetic inactivation is mostly ascribed to its conformation mutations and allelic deletion. Mutant p53 not only acts as a tumor suppressor but can also exhibit tumor-promoting effects. Mutated gene encodes for a mutant protein with a higher cellular stability.[6] These mutations are generally found in the exons 5-8 of the p53 gene and are related with poor prognosis in some human tumors, such as oral, lung, and breast, prostate and colorectal tumors. Mutation in the p53 gene is the most common genetic aberration encountered in oral premalignant lesions and squamous cell carcinoma in situ.[6]Therefore, in this study, we aimed to determine the $\mathrm{C}$-deletion in exon 4 codon 63 of p53 gene in a Turkish population.

\section{Materials and Methods}

\section{Study Population}

This case-control study included 30 OSCC patients (18 males and 12 females, mean age: $58.63 \pm 12.13$ years) and 30 unrelated healthy controls (19 males and 11 females, mean age: $62.77 \pm 12.06$ years). All OSCC patients were histopathologically confirmed and were recruited from the Department of Medical Oncology, Faculty of Medicine, Gaziosmanpasa University (Tokat, Turkey). The healthy control group was similar concerning age and sex distribution; and they did not have any evidence of OSCC or any other oral diseases. Informed written consent was obtained from all subjects. This study protocol was approved by the Local Ethics Committees (2017-14/154) in accordance with the ethical standard for human experimentation established by the Declaration of Helsinki.

\section{Genotyping}

The DNA of the participants was isolated from peripheral blood mononuclear cells using a DNA extraction kit, according to the manufacturer's instructions (Sigma-Aldrich, Taufkirchen, Germany). The C-deletion in exon 4 codon 63 of p53 gene was genotyped in all the subjects by the polymerase chain reaction (PCR) analysis, as described method previously.[7] PCR reaction was carried out in a $25 \mu \mathrm{l}$ reaction volume containing $1 \mu \mathrm{g} / \mu \mathrm{l}$ of genomic DNA, $2.5 \mu \mathrm{l}$ of $10 \mathrm{X}$ Taq polymerase buffer with $1.5 \mathrm{mM} \mathrm{MgCl}_{2}, 200 \mu \mathrm{M}$ of each dNTPs, $15 \mu \mathrm{g}$ of each primer and 1 unit of Taq DNA polymerase $\mu \mathrm{l}$. On the basis of sequence, the primers were constructed for C-deletion on codon 63 of exon 4 of p53 gene as F- 5' GGTCCAGATGAAGTCCCAGAA and R-5'-CGTGCAAGTCACAGACTTGGC. A negative control, without template DNA was included in each round of reactions. PCR thermal was performed in 35 cycles. Each cycle consisted of $94^{\circ} \mathrm{C}$ denaturation for $45 \mathrm{~s}, 57^{\circ} \mathrm{C}$ annealing for $45 \mathrm{~s}$, and $72^{\circ} \mathrm{C}$ extension for $1 \mathrm{~min}$. The thermal cycles were started with an initial denaturation of $96^{\circ} \mathrm{C}$ for $5 \mathrm{~min}$ and a final $72^{\circ} \mathrm{C}$ extension for $10 \mathrm{~min}$ for polishing the ends of PCR products. The thermalcycles were started with an initial denaturation of $96^{\circ} \mathrm{C}$ for $5 \mathrm{~min}$ and a final $72^{\circ} \mathrm{C}$ extension for $10 \mathrm{~min}$ for polishing theends (making smooth) of PCR products.

\section{Construction of Primer Against C Deletion on Exon 4 of p53 Gene}

On the basis of sequence, the primers were constructed for $\mathrm{C}$ deletion on codon 63 of exon 4 of p53 gene as 5'-GGTCCAGATGAAGTCCCAGAA (upstream) and 5'-CGTGCAAGTCACAGACTTGGC (downstream). The annealing temperature of constructed primers was estimated as $58^{\circ} \mathrm{C}$ and the PCR amplification reaction was done as described above.

\section{Agarose Gel Electrophoresis}

Resulting PCR products were resolved (15 $\mu$ PCR product mixed with $2 \mu$ l gel loading dye) on $1.5 \%$ agarose gel using submarine gel electrophoresis for one hour in $1 \mathrm{X}$ TBE buffer (Tris $\mathrm{HCl}$, boric acid, EDTA; $\mathrm{pH}$ 8.0). Subsequently, gels were stained with ethidium bromide (10 mg/l) and photographed on a UV transilluminator using a gel documentation system.

\section{Statistical Analysis}

All statistical analyses were performed with the Statistical Package for the Social Science for Windows (version 18.0; SPSS Inc., Chicago, IL, USA). Continuous data were given as means \pm SD and minimum/maximum. The $\chi^{2}$ test was used to measure significance of differences in the allele frequency and genotype distribution between the two study groups. Odds ratio (OR) and $95 \%$ confidence intervals (CI) were calculated. A p-value $\leq 0.05$ was considered statistically significant. 


\section{Results}

A total of 60 subjects were included in the present study. Age, gender, and age at the time diagnosis were analyzed. Demographic characteristics of the study participants are shown in Table 1.

The C-deletion mutation in exon 4 codon 63 of p53 gene among the OSCC patients and controls are shown in Table 2. There was a significant difference between OSCC patients and controls. All patients appeared Cdeletion exon 4 codon 63 of $\mathrm{p} 53$ gene $(\mathrm{p}=0.000)$.

\section{Discussion}

OSCC is one of the most common oral cancers. Tobacco and alcohol consumption is the most important risk factors for OSCC, but a genetic predisposition has also been implied given that the most of the population exposed to these risk factors do not have oral cancer and that sporadic cases of oral tumors are seen in young adults and nonusers of tobacco and alcohol.

Carcinogenesis is a complicated and multi-factorial process in which genetic events within signal transduction pathways executing normal cellular physiology are changed. [8] Cancer is the result of an amassing of alterations in the excitatory and inhibitory cellular pathways, which may take place at any level of a certain pathway. It is believed that somatic mutations ranging between three to six are required for transforming a normal cell into its malignant one.[8] p53 is an important tumor supressor gene. This gene found on chromosome 17p 13.1 encodes a 53-kDa, 393 amino

\begin{tabular}{|c|c|c|}
\hline \multirow[t]{2}{*}{ Table 1} & \multicolumn{2}{|c|}{$\begin{array}{l}\text { The demographical characteristics of the study } \\
\text { subjects }\end{array}$} \\
\hline & $\begin{array}{l}\text { Patient group } \\
(\mathbf{n}=\mathbf{3 0})\end{array}$ & $\begin{array}{c}\text { Control group } \\
(\mathbf{n}=\mathbf{3 0})\end{array}$ \\
\hline Age & $58.63 \pm 12.13$ & $62.77 \pm 12.06$ \\
\hline \multicolumn{3}{|l|}{ Gender } \\
\hline Female & $12(40.0)$ & $11(36.7)$ \\
\hline Male & $18(60.0)$ & $19(63.3)$ \\
\hline Diagnosis age & $56.93 \pm 9.35$ & \\
\hline
\end{tabular}

acid nuclear phosphoprotein. Wild-type p53 protein functions as a DNA-binding transcription factor and results in the control of the cell cycle by G1/S phase detainment following sublethal DNA damage.Hence, providing extra time for repair prior replication or the induction of apoptosis if the damage is too severe.[9] It is also believed that of over half of human tumors that display mutations in the $\mathrm{p} 53$ gene have dysfunctional p53 signaling. The prevalence of p53 mutations also depend on the tumor type. The majority of p53 mutations found in human cancer map to the DNA-binding surface of the $\mathrm{p} 53$ protein, comprising two large loops, L2 (residues 163-195) and L3 (residues 236-251) and a loop-sheet-helix motif.[10]

Comprehensive genomic studies have indicated that p53 mutations occur commonly in head and neck squamous cell cancers. Missense, stop-gain, splice site, frameshift deletions, and inframe deletions are among the various types of p53 mutations that are implicated in the early stages during the carcinogenetic process of the corresponding epithelia. Missense and truncating mutations are related with malignant cell proliferation, enhanced invasion, and resistance to chemotherapeutic regimens. All of these histological and biochemical factors play a role in poor prognosis (decreased drug response rates and short survival span), particularly in missense mutations carriers. Lazarus et al. reported that incidence of p53 mutations have been found in approximately $63 \%$ of OSCC.[11] Hsieh and Wang et al.reported that mutation in $\mathrm{p} 53$ is detected in $48 \%$ of tumor samples. [12] Zanaruddin et al. found that p53 mutations were present in $27.7 \%$ of the OSCC specimens.[13] A study group analyzed a large number of OSCC tissues and found that p53 mutations are associated with lower survival rates in these patients.[14]

In this study, we investigated the association between C-deletion exon 4 codon 63 of p53 and OSCC in Turkish patients. To our knowledge, this research is the first to study evaluating this deletion in our OSCC patients. We found that all patients had $\mathrm{C}$ deletion mutation in exon 4 codon 63 of p53 gene. The patients carrying $\mathrm{p} 53 \mathrm{C}$ deletion had 17.957-fold increased risk for

Table 2 C-deletion mutation in exon 4 codon 63 of p53 gene in groups

\begin{tabular}{lccc} 
C-deletion exon $\mathbf{4}$ codon 63 & $\begin{array}{c}\text { Patient group } \\
\mathbf{n}(\%)\end{array}$ & $\begin{array}{c}\text { Control group } \\
\mathbf{n}(\%)\end{array}$ & $\boldsymbol{\chi}^{\mathbf{2}}$ \\
\hline Positive & $30(100)$ & $16(53.3)$ & 17.957 \\
Negative & $0(0)$ & $14(46.7)$ & 0.000 \\
\hline
\end{tabular}


OSCC $(p=0.000)$. High mutation rate may be due to ethnic differences.

There were several limitations to this study.Expression of p53 in biopsy tissue samples was not studied. Secondly, study population represented relatively small sample size. Also, the absence of examination of other mutations regarding p53 is another limitation.

\section{Conclusion}

p53 mutations are heterogeneous and act through a complex and intricate network of multiple proteins. Clinically, p53 mutations are crucially linked with poor survival and tumor resistance to radiotherapy and chemotherapy in OSCC patients, which implies that p53 mutations can be used as a marker that can bear prognostic and predictive value concerningclinical response. Also, the development of efficient and longlasting therapeutic modalities for OSCC patients with tumors having p53 mutations is needed. In this study, all patients hadC-deletion mutation in exon 4 codon 63 of p53.Therefore, we think our results are important because they reflect Turkish patient profile. This data may help providing novel treatment options.

Peer-review: Externally peer-reviewed.

Conflict of Interest: The authors declare that they have no conflict of interest.

Ethics Committee Approval: This study protocol was approved by the Local Ethics Committees in accordance with the ethical standard for human experimentation established by the Declaration of Helsinki.

Financial Support: This study was supported by Ahi Evran University BAP (SYO.A4.16.002) program.

Authorship contributions: Concept - A.T., S.Y., O.G.; Design - S.Y., A.F.N.; Supervision - O.G., A.F.N.; Funding None; Materials - S.Y., M.K.T., O.G.; Data collection and/or processing - A.T., O.G.; Data analysis and/or interpretation - S.Y., A.F.N.; Literature search - A.F.N., M.K.T.; Writing A.F.N.; Critical review - S.Y., S.Y., M.K.T.

\section{References}

1. Nagpal JK, Das BR. Oral cancer: reviewing the present understanding of its molecular mechanism and exploring the future directions for its effective management. Oral Oncol 2003;39(3):213-21.
2. Johnson NW, Jayasekara P, Amarasinghe AA. Squamous cell carcinoma and precursor lesions of the oral cavity: epidemiology and etiology. Periodontol 2000 2011;57(1):19-37.

3. Liao PH, Chang YC, Huang MF, Tai KW, Chou MY. Mutation of p53 gene codon 63 in saliva as a molecular marker for oral squamous cell carcinomas. Oral Oncol 2000;36(3):272-6.

4. Lane DP. Cancer. p53, guardian of the genome. Nature 1992;358(6381):15-6.

5. Athar M, Elmets CA, Kopelovich L. Pharmacological activation of p53 in cancer cells. Curr Pharm Des 2011;17(6):631-9.

6. Ara N, Atique M, Ahmed S, Ali Bukhari SG. Frequency of $\mathrm{p} 53$ gene mutation and protein expression in oral squamous cell carcinoma. J Coll Physicians Surg Pak 2014;24(10):749-53.

7. Sukhija H, Krishnan R, Balachander N, Raghavendhar $\mathrm{K}$, Ramadoss R, Sen S. C-deletion in exon 4 codon 63 of p53 gene as a molecular marker for oral squamous cell carcinoma: A preliminary study. Contemp Clin Dent 2015;6(Suppl 1):S227-34.

8. Vogelstein B, Kinzler KW. The multistep nature of cancer. Trends Genet 1993;9(4):138-41.

9. Ko LJ, Prives C. p53: puzzle and paradigm. Genes Dev 1996;10(9):1054-72.

10. Cho Y, Gorina S, Jeffrey PD, Pavletich NP. Crystal structure of a p53 tumor suppressor-DNA complex: understanding tumorigenic mutations. Science 1994;265(5170):346-55.

11.Lazarus P, Stern J, Zwiebel N, Fair A, Richie JP Jr, Schantz S. Relationship between p53 mutation incidence in oral cavity squamous cell carcinomas and patient tobacco use. Carcinogenesis 1996;17(4):7339.

12. Hsieh LL, Wang PF, Chen IH, Liao CT, Wang HM, Chen MC, et al. Characteristics of mutations in the p53 gene in oral squamous cell carcinoma associated with betel quid chewing and cigarette smoking in Taiwanese. Carcinogenesis 2001;22(9):1497-503.

13.Zanaruddin SN, Yee PS, Hor SY, Kong YH, Ghani WM, Mustafa WM, et al. Common oncogenic mutations are infrequent in oral squamous cell carcinoma of Asian origin. PLoS One 2013;8(11):e80229.

14. Lapke N, Lu YJ, Liao CT, Lee LY, Lin CY, Wang HM, et al. Missense mutations in the TP53 DNA-binding domain predict outcomes in patients with advanced oral cavity squamous cell carcinoma. Oncotarget 2016;7(28):44194-210. 